\title{
PESAN RELIGIUS PADA TEGAKNYA MASJID KAMI (SEBUAH NOVEL SEJARAH DI TANAH BANJAR) KARYA TAJUDDIN NOOR GANIE
}

\author{
Muhammad Saihu
}

SDN 1 Sari Mulya

email: saihujaderi@gmail.com

\begin{abstract}
ABSTRAK
Sastra yang merupakan sebuah seni menjadi sesuatu hal yang menarik untuk diamati. Hal ini dikarenakan seni sendiri berbentuk keindahan bagi yang mengamatinya, bukan hanya itu, seni juga dianggap memiliki nilai dan makna yang implisit sehingga semakin diamati maka semakin banyak hal yang menjadi nilai-nilai sebagai pesan dari sastra.

Sastra yang berupa seni dan karya tersebut sangat berhubungan erat dengan sebuah ekspresi penciptaan dan kegiatan penciptaan. Ekspresi penciptaan ini berupa pengekspresian seorang pencipta atau pembuat yang memuat berbagai unsur kemanusiaan yang ada di dalamnya. Artinya, ketika sastra berhubungan erat dengan ekspresi penciptaan maka ketika sastra ini diciptakan maka mengandung unsur-unsur kemanusiaan.Masyarakat memiliki keyakinan tentang apapun yang dianggapnya sesuai dengan keyakinannya. Dalam hal ini, berkenaan dengan agama. Orang yang mengamalkan serta patuh terhadap aturan agama ini dianggap sebagai orang yang religius. Keriligiusan seseorang tampak dari bagaimana sikapnya dalam menghadapi sesuatu setiap hari. Begitu pula dalam Novel sejarah di Tanah Banjar dengan judul Tegaknya Masjid Kami yang dikarang oleh Tajuddin Noor Ganie menceritakan bagaimana keriligiusan masyarakat Banjar yang akhirnya mampu membangun sebuah mesjid yang dijadikan sebagai tempat ibadah.

Metode dalam penelitian ini adalah berupa kualitatif. Adapun pendekatan yang digunakan adalah dengan menggunakan pendekatan sosiologis, yaitu untuk mengetahui bagaimana cara manusia menyesuaikan diri dalam sebuah komunitas masyarakat. Metode yang digunakan adalah deskriptif analisis. Hasil yang didapatkan dalam pesan pesan religius pada Tegaknya Masjid Kami (Sebuah Novel Sejarah di Tanah Banjar) ini berupa sikap berani, syukur, dan sabar.
\end{abstract}

Kata Kunci: pesan, religius, sastra, novel

\section{PENDAHULUAN}

Sastra yang merupakan sebuah seni menjadi sesuatu hal yang menarik untuk diamati. Hal ini dikarenakan seni sendiri berbentuk keindahan bagi yang mengamatinya, bukan hanya itu, seni juga dianggap memiliki nilai dan makna yang implisit sehingga semakin diamati maka semakin banyak hal yang menjadi nilai-nilai sebagai pesan dari sastra. Bukan hanya sebagai seni, sastra itu berupa karya para pelakunya yang memiliki nilai esetetis, yaitu nilai keindahan yang memiliki daya tarik dalam penciptaannya karena dibuat dengan kreatifitas imajinasi yang kapabilitasnya tidak dimiliki oleh setiap orang. Karya Sastra adalah sesuatu diungkapkan secara komunikatif yang mengandung maksud pembuat tulisan dengan tujuan estetika. 
Sastra merupakan seni dan karya yang berkaitan dengan ekspresi dan kegiatan penciptaan. Karena hubungannya dengan ekspresi, maka karya sastra sangat banyak mengandung unsur kemanusiaan. Antara lain seperti perasaan, semangat, kepercayaan, keyakinan sehingga mampu membangkitkan kekaguman. Di dalam karya sastra terdapat nilai-nilai di kehidupan nyata yang sengaja diciptakan penulis, nilai-nilai itu berupa agama, sosial, budaya, filsafat, dan politik. Nilainilai itu tidak dapat berdiri sendiri karena semuanya merupakan suatu kaitan yang tidak dapat dipisahkan (Mirnawati, 2017: 1)

Sastra yang berupa seni dan karya tersebut sangat berhubungan erat dengan sebuah ekspresi penciptaan dan kegiatan penciptaan. Ekspresi penciptaan ini berupa pengekspresian seorang pencipta atau pembuat yang memuat berbagai unsur kemanusiaan yang ada di dalamnya. Artinya, ketika sastra berhubungan erat dengan ekspresi penciptaan maka ketika sastra ini diciptakan maka mengandung unsur-unsur kemanusiaan. Ekspresi ini bisa berupa rasa yang ada dalam diri manusia, seperti bagaimana sastra itu mengekepresikan rasa percaya diri, kagum, yakin, semangat, sedih, dan yang ekspresi lainnya yang ada pada diri manusia. Dengan adanya ekspresi manusia yang tertuang dalam sastra ini maka sastra pun memiliki nilai-nilai yang terkandung sesuai dengan harapan penulisnya. Ekspresi adalah ungkapan perasaan pelaku seni. Perasaan yang dimaksud adalah perasaan khusus yang dapat membagun sikap serta nilai. Ekspresi diartikan juga sebagai mimik muka atau kesan wajah untuk menyatakan atau mengungkapkan maksud, perasaan dan gagasan.

Bahkan, sastra ini juga digunakan sebagai kritik gejala sosial masyarakat, baik di ranah masyarakat pada umumnya maupun pemangku-pemangku kebijakan pada khususnya. Kemudian, sastra yang berhubungan dengan penciptaan mengisyaratkan bahwa dalam penciptaan sastra mengandung berbagai nilai-nilai yang ingin disampaikan oleh penulisnya. Penulis ingin menyampaikan sesuatu kepada para pembaca secara implisit sehingga pembaca perlu memahami dengan baik tentang apa yang ingin disampaikan dalam sastra.

Karya sastra bagian dari kebudayaan. Artinya, karya sastra bisa saja merefleksikan kejadiankejadian fakta, baik sosial maupun secara historis dari sebuah tempat, tokoh, maupun yang lainnya. Lahirnya karya sastra di tengah masyarakat tidak terlepas dari pengaruh-pengaruh sosial masyarakat. Sastra bisa saja mempengaruhi dan bisa juga dipengaruhi masyarakat. Karya sastra ini selalu melibatkan sosial kehidupan masyarakat. Setiap persoalan, kejadian, peristiwa terekam dengan baik melalui sebuah karya sastra. Hal ini dikarenakan karya sastra mampu mengimajinasikan berbagai peristiwa yang ada ke dalam pikiran-pikiran manusia, baik secara fiktif maupun fakta berdasarkan dengan peristiwa atau kejadian atau dengan tokoh yang memang dari 
sesuatu hal yang tidak fiktif. Akan tetapi, secara pengungkapannya digunakan bahasa estetik yang mampu membuat para pembacanya berimajinasi sesuai dengan karya yang dibuat. Oleh karena itu, dalam hal ini, sangat jelas sekali bahwa sastra menjadikan manusia sebagai objeknya untuk melihat gejala yang ada pada manusia untuk dijadikan sebuah karya.

Salah satu kebudayaan yang sangat dijunjung oleh masyarakat adalah berkenaan dengan keyakinan. Masyarakat memiliki keyakinan tentang apapun yang dianggapnya sesuai dengan keyakinannya. Dalam hal ini, berkenaan dengan agama. Orang yang mengamalkan serta patuh terhadap aturan agama ini dianggap sebagai orang yang religius. Keriligiusan seseorang tampak dari bagaimana sikapnya dalam menghadapi sesuatu setiap hari. Begitu pula dalam Novel sejarah di Tanah Banjar dengan judul Tegaknya Masjid Kami yang dikarang oleh Tajuddin Noor Ganie menceritakan bagaimana keriligiusan masyarakat Banjar yang akhirnya mampu membangun sebuah mesjid yang dijadikan sebagai tempat ibadah. Jadi, pesan-pesan religius ini merupakan salah satu dari pesan moral sebagaimana yang disampaikan oleh Nurgiyantoro dengan pengutipnya Fatimah (2016: 8) mengungkapkan bahwa pesan moral yang berwujud moral religius, termasuk di dalamnya yang bersifat keagamaan...

Dari hal yang telah diuraikan di atas maka menarik kiranya untuk mengamati tentang pesan religiusitas yang ada pada novel sejarah di tanah Banjar dengan judul Tegaknya Masjid Kami. Adapun pembahasan ini akan dititikberatkan bagaimana pesan-pesan religius yang terdapat pada cerita di dalamnya.

\section{METODE}

Jenis dalam penelitian ini adalah berupa kualitatif, yaitu berhubungan analisis deskriptif. Menganalisis bagaimana gejala-gejala sosial yang ada pada Tegaknya Masjid Kami (Sebuah Novel Sejarah di Tanah Banjar) kemudian menggambarkan hasil yang sudah didapatkan dari analisis tersebut. Ratna (2015: 53) menyatakan bahwa metode penelitian dapat juga diperoleh melalui gabungan dua metode, dengan syarat kedua metode tidak bertentangan. Metode deskrptif analisis dilakukan dengan cara mendeskripsikan fakta-fakta yang kemudian disusul dengan analisis. Secara etimologis deskripsi dan analisis berarti menguraikan. Meskipun demikian, analisis yang berasal dari bahasa Yunani, analyein ('ana' = atas, 'lyein' = lepas, urai), telah diberikan arti tambahan, tidak semata-mata menguraikan melainkan juga memberikan pemahaman dan penjelasan secukupnya. 
Adapun pendekatan yang digunakan adalah dengan menggunakan pendekatan sosiologis, yaitu untuk mengetahui bagaimana cara manusia menyesuaikan diri dalam sebuah komunitas masyarakat. Bahkan, Ratna (2015: 59) menyatakan berkenaan dengan pendekatan sosiologis ini, yaitu disebutkan beliau bagaimana pendekatan ini menganalisis manusia dalam masyarakat, dengan proses pemahaman mulai dari masyarakat ke individu.

Metode yang digunakan adalah deskriptif analisis, yaitu dilakuakan dengan cara mendeskripsikan fakta-fakta yang kemudian disusul dengan analisis (Ratna, 2015: 53). Adapun teknik penelitian ini dengan mengikuti langkah-langkah.

1. Membaca cerpen secara menyeluruh

2. Mengklasifikasikan data sesuai dengan kritik sosial

3. Interpretasi, yaitu pemberian makna terhadap data yang sudah diklasifikasikan

4. Analisis data, yaitu menganalis yang sesuai dengan kritik sosial

5. Menyimpulkan, yaitu pemberian simpulan

\section{HASIL DAN PEMBAHASAN}

1. Religius

Nurgiyantoro (2010: 327) menyatakan bahwa pada mula segala sastra adalah religius. Istilah religius membawa konotasi pada makna agama. Religius dan agama erat berkaitan, berdampingan, bahkan dapat melebur dalam satu kesatuan, namun sebenarnya keduanya menyaran pada makna yang berbeda. Seorang yang religius adalah orang yang mencoba memahami dan menghayati hidup dan kehidupan ini lebih dari sekedar lahiriah saja. Dia tidak terikat pada agama tertentu yang ada di dunia ini. Artinya, religius ini berkenaan dengan pengamalan dari perintah agama itu sendiri. Ketika perintah agama itu diamalkan dan dibawa dalam kehidupan sehari-hari sebagai pedoman hidup maka sudah memiliki hidup yang religi, yaitu hidup yang berlandaskan aturan-aturan atau konsep yang ada pada agama.

Ditambah lagi, pengamalan-pengamalan terhadap apa yang diperintahkan agama ini biasanya akan berbentuk sebuah sikap dari pelakunya. Misalnya saja, ketika di jalan dia menemukan sebuah dompet yang berisi uang, maka bagi mereka yang mengamalkan aturan di dalam sebuah agama maka akan mengembalikannya. Hal ini menandakan adanya sebuah sikap kejujuran, kemudian juga adanya sikap bertanggung jawab atau amanah terhadap benda yang ditemukan tersebut sehingga dikembalikan kepada pemiliknya. Ini adalah salah satu contoh dari pengamalannya. 


\section{Pesan Religius}

Pesan berarti sebuah amanat. Pesan religius adalah pelajaran religi atau pesan yang di dapat dari suatu kejadian, pengalaman seseorang, atau dari sebuah novel yang dapat memberikan pelajaran hidup secara religi bagi pembacanya. Bisa juga, pesan ini berupa nilai-nilai yang terkandung dalam sebuah karya sastra, yang pada hal ini sebuah pesan religi yang ada pada Tegaknya Masjid Kami karya Tajuddin Noor Ganie. Adapun pesan yang terdapat pada novel sejarah di tanah Banjar ini, yaitu.

\section{a. Berani}

Berani mempunyai hati yang mantap dan rasa percaya diri yang besar dalam menghadapi bahaya, kesulitan, dan sebagainya. Berani artinya memiliki semangat menerima segala yang ditakdirkan atau ketangguhan seseorang terhadap apa yang dihadapinya. Atau juga berani ini diartika sebagai kerelaan dan kesiapan mental menanggung semua resiko yang ditumbulkan dari perbuatannya. Memiliki kepercayaan diri dalam menghadapi tantangan dari menegakkan yang benar. Dan ini disebut dikap bertanggungjawab. Sikap keberanian lahir dari keyakinan bahwa kebenaran hanya datang dari Allah yang Maha Benar. Maka siapapun membela kebenaran ini berarti ia membela Allah. Di sinilah tumbuh keyakinan kuat bahwa dalam kebenaran Allah bersamanya (Ritonga, 2005-211).

Sikap berani ini sayogiyanya sudah terpupuk di dalam diri. Siapa saja yang memiliki sikap berani berarti dia memiliki sikap menerima, tidak pantang menyerah terhadap apa yang dihadapinya. Walaupun yang dihadapi ini adalah sesuatu yang berat maka dia akan tetap menjalani dan mencoba mencari solusi terhadapnya.

Seorang yang berani itu adalah hal baik dalam diri manusia. Dengan begitu, kamu tidak akan mudah ditindas dan kuat menghadapi segala macam permasalahan. Namun, hal berani yang dimaksud dari sisi positifnya seperti berani bersuara atau menyampaikan sesuatu kepada orang lain, berani karena benar, berani mengubah cara pandang, dan masih banyak lainnya. Artinya, sikap berani perlu dimiliki oleh setiap orang. Bahkan, dalam kutipan di bawah ini mengungkapkan keberanian seseorang terhadap sesuatu yang menghalanginya.

Lihat kutipan B4.T6 berikut.

"kalau saya boleh tahu, ke mana kalian berdua ingin mencari kayu ulin untuk tiang guru masjid dimaksud?' tanya punggawa kerajaan.

"ke pulau kaget," kali ini Stutakul yang menjawab.

“ke pulau kaget?” tanya punggawa kerajaan dengan nada heran. 
“Ya, ke pulau kaget. Memangnya kenapa, tuan punggawa?’ jawab Sutakil dan Sutakul hampir bersamaan.

"Ah, tidak apa-apa. Cuma ..."

“Cuma apa, tuan punggawa?” desak Sutakul.

"Apakah kalian berdua sudah mendengar cerita tentang...”

"Keangkeran Pulau Kaget?” Sambar Sutakil.

"Ya, begitulah maksudku," ujar punggawa itu lagi.

"Sudah. Tapi kami berdua tidak takut."

"Baiklah kalau begitu. Kapan kalian pergi ke sana?"

"Subuh besok,” jawab Sutakil.

"Kalau begitu baiklah. Selamat jalan. Semoga kalian sukses. Hanya itu yang bisa saya ucapkan."

"Terima kasih, tuan punggawa."

Kutipan di atas menunjukkan keberanian dari dua orang bersaudara yang mengikuti sayembara mencari kayu ulin yang digunakan untuk tongkat pembangunan masjid di kerajaan Banjar. Sutakil dan Sutakul adalah dua orang saudara kembar yang tidak pernah terdengar sakti mandraguna yang mengikuti sayembara ini. Bahkan, mereka mengatakan bahwa akan mencari kaytu ulin tersebut di Pulau Kaget. Pulau Kaget sendiri dikenal sebagai pulau angker yang tidak berpenghuni serta banyak makhluk gaib yang mendiaminya. Punggawa kerajaan yang mendengar jawaban dari mereka yang mau mencari kayu ulin ke Pulau Kaget pun heran dan bertanya kepada mereka dan mengatakan juga bahwa tempat tersebut dikenal angker dan berbahaya. Akan tetapi, Sutakil dan Sutakul pun menjawab bahwa mereka tidak takut.

Pernyataan tidak takut dari Sutakil dan Sutakul adalah salah satu bentuk sikap berani. Rasa penyerahan dirinya begitu dalam sehingga tidak menipiskan keberanian untuk ke pulau itu untuk mencari kayu ulin. Kayu ini nanti sayogiyanya sebagai tongkat pembangunan masjid. Jadi, inilah adalah salah satu tindakan berani yang ada pada diri Sutakil dan Sutakul. Tindakan ini tampak pada ucapannya yang tidak takut dengan apapun termasuk keangkeran yang ada di Pulau Kaget.

\section{b. Syukur}

Syukur adalah sebuah ungkapan terima kasih kepada tuhan yang Maha Esa. Syukur ini memuji zat yang memberi kenikmatan atas limpahan kebaikan yang dianugerahkan-Nya. Ubaid (2012-171) mengungkapkan bahwa syukur itu dilakukan dengan hati, lisan, dan anggota badan. Bersyukur dengan hati berarti meniatkannya untuk kebaikan semua makhluk. Sedangkan bersyukur dengan lisan berarti menunjukkan rasa syukur itu kepada Allah dengan memujinya sambil mengucapkan hamdallah. Sikap syukur paling sederhana adalah mengucapkan Alhamdulillah (segala puji bagi Allah) setiap mendapat kenikmatan. Sikap syukur yang lebih luas diwujudkan 
dalam bentuk taat kepada Allah, mematuhi dan melaksanakan segala perintah-Nya, sekaligus menninggalkan segala larangan-Nya. Jadi, syukur ini adalah rasa terima kasih yang ada dalam diri terhadap apa yang sudah diberikan kepada sang pencipta.

Lihat kutipan B3.T13 berikut.

"Anakda Sultan Suriansyah. Dari hari ke hari semakin banyak saja warga negara kerajaan Banjar yang memeluk agama Islam. Sehubungan dengan itu, ayahanda berpendapat bahwa sudah tiba saatnya bagi anakda untuk membangun sebuah masjid yang cukup memadai daya tampungnya di pusat kota Muara Banjar ini. Selain bisa difungsikan sebagai tempat menyelenggarakan shalat Jum'at, masjid dimaksud juga bisa dimanfaatkan oleh para ulama untuk mengajarkan ilmu-ilmu keagamaan yang dimilikinya kepada para pemeluk agama Islam," ujar Khatib Dayan menyarankan kepada Sultan Suriansyah.

"Benar sekali, ayahanda. Anakda juga berpikiran demikian. Sesungguhnya, sudah sejak lama anakda ingin membangun masjid sebagaimana ayahanda sarankan itu. Bahkan, anakda sudah memilih lokasi pembangunannya, yakni di tepi Sungai Kuin tak jauh dari istana Kuin."

"syukurlah, kalau begini."

Teks di atas menunjukkan rasa syukur yang diucapkan oleh Khatib Dayan karena usulannya telah diterima oleh Sultan Suriansyah. Khatib Dayan melihat bahwa masyarakat Banjar sudah mulai banyak memeluk agama Islam. Hal ini akhirnya membuat Khatib Dayan berpikir agar Sultan Suriansyah segera membangun sebuah masjid sebagai tempat ibadah dan tempat kajian ilmu agama. Setelah itu, dia pun menyampaikannya kepada Sultan Suriansyah. Karena ide itu ternyata juga sesuai dengan pemikiran Sultan Suriansyah, Khatib Dayan pun merasa bersyukur karena apa yang dipikirkan sesuai dengan pikiran Sultan Suriansyah dan usulannya untuk membangun sebuah masjid disetujui maka ia pun merasa bersyukur dengan ucapan syukur.

Pada kutipan B3.T13 di atas jelas sekali bahwa rasa syukur itu berupa ucapan yang dibarengi dengan pengiyaan dalam diri terhadap apa yang didapatkan. Syukur ini bisa saja diucapkan dan bisa juga keluar dari tindakan-tindakan yang mengungkapkan rasa syukur.

\section{c. Sabar}

Sabar ini berkenaan dengan bagaimana menahan diri dalam berkeluh kesah, menerima takdir sesuai yang sudah ditakdirkan yang maha kuasa akan tetapi tetap berusaha untuk merubah takdir yang ada agar lebih baik lagi. Ritonga (2005: 201) memberikan definisi bahwa sabara adalah sikap mental yang teruji kekuatannya dalam menghadapi berbagai ragam ujian dan tantangan. Sabar 
adalah kemampuan menguasai diri dan emosi dari kemarahan, kebencian, dendam serta sanggup melaksanakan tugas-tugas amal saleh. Maka sabar merupakan kekuatan batin, karena dengan sabar ia dapat menguasai dan memimpin dirinya sehingga tidak melakukan perbuatan yang merugikan dirinya sendiri dan orang lain.

Lihat kutipan B1.T23 berikut.

Keberangkatan Pengeran Samudera tidak mengetahui bahwa dirinya sebenarnya masih tetap dikawal, tetapi pengawalannya dilakukan secara tertutup atau tidak langsung. Sesuai dengan status Pangeran Samudera sebagai buronan yang paling dicari oleh kaki tangan Pangeran Tumenggung, maka pengawal pribadi Pangeran Samudera sengaja dipilihkan orang-orang yang sakti mandraguna.

Sejak pagi buta, Pangeran Samudera sudah berangkat mencari ikan dan siang hari sekiotar pukul 08.00-10.00 ia sudah mengayuh perahunya berkeliling kampung sambil menjajakan ikan hasil tangkapannya hari itu. Semua kegiatannya itu dilakukan Pangeran Samudera tanpa meninggalkan perahu kesayangannya, karena tempatnya mencari ikan memang di sungai dan tempatnya menjajakan ikan hasil tangkapannya adalah para ibu rumah tangga yang kesemuanya memang tinggal di perkampungan-perkampungan tepi sungai.

Kutipan di atas menunjukkan bagaimana kesabaran Pangeran Samudera menjalani masa pelariannya. Apabila kita melihat dari status sosial maka kita melihat bahwa dia adalah seorang pangeran yang seharusnya dilayani. Akan tetapi, dengan sabar dia menjalani kehidupannya dengan mengayuh perahu kemudian mencari ikan. Ikan-ikan tersebut kemudian dijualnya kepada para ibuibu yang ada di kampung-kampung. Artinya, dalam kutipan di atas, menunjukkan kesabaran seorang Sultan Suriansyah yang pada masa pelarian dan masih menjadi seorang pangeran berusaha dengan sungguh-sungguh tanpa memandang status sosialnya sebagai seorang bangsawan. Kesabaran ini terbentuk dari didikan dari lingkungan keluarga serta masyarakat. Sebagaimana dari pengertian sabar yaitu mampu menahan diri. Artinya, pangeran pada hal ini mampu menahan diri, tidak membuka jati dirinya sebagai seorang bangsawan. Bahkan, ia juga tetap bekerja seperti masyarakat biasa pada umumnya.

Manusia selalu ingin mendapatkan takdir yang baik. Dalam kehidupannya, manusia selalu ingin hidup sesuai dengan rencananya. Hidup dipenuhi harta dan karirnya juga baik. Akan tetapi, kadang, tuhan memberikan sebuah cobaan terhadap manusia. Dalam hal ini, manusia diberikan sesuatu yang dianggap aib dalam masyarakat. Dalam menghadapinya, diperlukan kesabaran, mau menerima takdir yang sudah diberikan tuhan. Artinya, perlu sikap sabar dalam menerimanya. Sikap sabar ini juga tercermin dari kutipan B2.T12 berikut. 
"Sabarlah, Bu. Mungkin sudah takdir kita berdua mempunyai anak seekor ular. Sebaiknya kita ambil hikmahnya saja, Bu,” ujar Abah kita mencoba menyabarkan perasaan istrinya.

Dalam kutipan tersebut sangat jelas sekali diucapakan dengan kata sabarnya. Diceritakan bagaimana orang tua dari Awi Tadung dan ular buntung melahirkan mereka. Kemudian, karena merasa bahwa yang dilahirkan salah satunya adalah ular maka orang tuanya pun terkejut. Akan tetapi, keterkejutan ini ternyata bisa disikapinya dengan sabar sehingga orang tua dari Awi Tadung pun menerima segala yang sudah ditakdirkan terutama kelahiran anaknya Awi Tadung dan ular buntung sebagai saudara kembar.

Melahirkan adalah sebuah anugerah yang diberikan oleh Tuhan yang Maha Esa. Akan tetapi, ketika yang dilahirkan itu adalah seekor ular bukan manusia maka akan dianggap menjadi aib bagi masyarakat. Pada kutipan di atas, bagaimana rasa sabar akhirnya bisa mengalahkan rasa malu terhadap aib. Ayah dan ibu dari Awi Tadung menerima dengan takdir yang sudah diberikan kepada mereka berdua.

\section{SIMPULAN}

Dari hasil dan pembahasan yang telah dibahas di atas maka dapat disimpulkan bahwa.

1. Pesan Religius adalah sebuah pesan yang berupa nilai-nilai pengamalan dari aturan-aturan agama dalam kehidupan sehari-hari.

2. Pesan religius yang terdapat dalam Tegaknya Masjid Kami (Sebuah Novel Sejarah di Tanah Banjar) karya Tajuddin Noor Ganie adalah (a) berani, (b) syukur, dan (c) sabar.

\section{DAFTAR RUJUKAN}

Endraswara, S. 2011. Metodelogi Penelitian Sastra. Yogyakarta: Medpress.

Ganie, T. N. 2011. Tegaknya Masjid Kami (Sebuah Novel Sejarah di Tanah Banjar). Tuas Media: Kalimantan Selatan.

Ritonga, R. 2005. Akhlak Merakit Hubungan dengan Sesama Manusia. Amelia: Surabaya.

Mirnawati. 2017. Pesan Moral dalam Kumpulan Cerpen Dongeng Kesetiaan karya Ratih Ayu Ningrum (Kajian Psikologi sastra). Skripsi, Tidak Diterbitkan. Banjarmasin: STKIP PGRI Banjarmasin.

Nurgiyantoro, B. 2010. Teori Pengkajian Fiksi. Yogayakarta: Gajah Mada Press. 
Ubaid, U. A. 2012. Sabar dan Syukur. Jakarta: Hamzah.

Ratna, N. K. 2013. Kajian Sastra, Seni, dan Sosial Budaya. Cetakan Pertama. Yogyakarta: Pustaka Pelajar. 